271 c.4. Мінтій I. С. Засоби формування у студентів педагогічних університетів компетентності в програмуванні на основі функціонального підходу / I. С. Мінтій // Вісник Черкаського університету. Серія педагогічні науки. - Випуск 191. Частина I. Черкаси : Вид. від. ЧНУ ім. Б. Хмельницького, 2010. - С. 86-92. 5. Мінтій І. С. Навчально-методичне забезпечення курсу «Вступ до програмування» / I. С. Мінтій // Матеріали VIII Міжнародної науково-технічної конференції : Київ-Севастополь, 14 17 вересня 2010 р. - К. : Міністерство регіонального розвитку та будівництва України, 2010. - С. 113-114. 6. Семеріков С. О. Теоретико-методичні основи фундаменталізації навчання інформатичних дисциплін у вищих навчальних закладах : дис. ... доктора пед. наук : 13.00 .02 «Теорія та методика навчання (інформатика)»/ Семеріков Сергій Олексійович; Національний педагогічний ун-т ім. М. П. Драгоманова. - К., 2009. - 369 с.

\title{
ФОРМУВАННЯ ПРОФЕСІЙНИХ ЗНАНЬ У МАЙБУТНІХ ПЕРЕКЛАДАЧІВ ТЕХНІЧНОЇ ЛІТЕРАТУРИ
}

Пизіна Є. В. Формування професійних знань у майбутніх перекладачів технічної літератури.

У статті описано процес формування професійних знань у студентів ВТНЗ майбутніх перекладачів технічної літератури із застосуванням інформаційнокомунікаційних технологій. Автор наводить конкретні приклади використовуваних нею форм, методів і прийомів навчання й описує отримані протягом педагогічного експерименту результати.

Ключові слова:професійна підготовка, компетенції перекладача, технічна література, ВТНЗ, професійні знання, інформаційно-комунікаційні технології.

Пызина Е. В. Формирование профессиональных знаний у будущих переводчиков технической литературы.

В статье описывается процесс формирования профессиональных знаний у студентов ВТУЗ - будущих переводчиков технической литературы с использованием информационно-коммуникационных технологий. Автор приводит конкретные примеры используемых ею форм, методов и приемов обучения и описывает результаты, полученные в ходе педагогического эксперимента.

Ключевые слова: профессиональная подготовка, компетенции переводчика, техническая литература, ВТУЗ, профессиональные знания, информационнокоммуникационные технологии.

Pyzina E. V. Building professional knowledge of future technical translators.

The article discusses how its author built professional knowledge of future technical translators in the students of technical universities with the help of information technologies. The researcher both provides her readers with real examples of the learning forms, methods, and techniques used and describes the results she has obtained during the educational experiment.

Key words: professional training, translator's competencies, technical literature, technical university, professional knowledge, information technologies.

Здатність перекладача технічної літератури ефективно виконувати свої професійні та суспільні обов'язки як посередника у всесвітньому науково-технічному 
прогресі повністю залежить від якості його професійної підготовки. Забезпечити належний рівень професійної підготовки перекладачів технічної літератури можна, якщо підвищити ефективність формування їх професійних компетенцій.

Професійні компетенції перекладача технічної літератури як інтегративні особистісні новоутворення містять чотири основні складники: мотиваційно-ціннісний, когнітивний, діяльнісний та рефлексивний. Проблема визначення того, що має знати професійний перекладач, неодноразово розглядалася в науково-педагогічній літературі. У різних аспектах іiї досліджували як вітчизняні (Є. Бесєдіна, І. Бахов [1], В. Желясков [2], О. Мацюк [4]), так і зарубіжні (В. Комісаров [3], Л. Латишев, Р. Мін'яр-Бєлоручев, В. Провоторов, І. Халєєва) науковці. Тим не менш, формування професійних знань перекладачів саме технічної літератури у студентів ВТНЗ із застосуванням інформаційнокомунікаційних технологій донині не ставала предметом окремої публікації.

Мета статmi- розкрити сутність формування професійних знань у студенів ВТНЗ - майбутніх перекладачів технічної літератури із застосуванням інформаційнокомунікаційних технологій (IКТ).

Формування професійних знань у майбутніх перекладачів технічної літератури здійснювалося в межах педагогічного експерименту 3 формування професійних компетенцій перекладачів технічної літератури у студентів ВТНЗ із застосуванням IКТ.

Поставлена мета забезпечити засвоєння майбутніми перекладачами технічної літератури знань про сутність професійної діяльності перекладача технічної літератури й зміст і структуру його/їі професійних компетенцій вимагала розширення та доповнення дисциплін гуманітарної, інформаційної і професійно-практичної підготовки через долучення до відповідних навчальних і робочих програм тем, які розширювали професійно значущий потенціал навчальних предметів.

Так, тему з теорії філософії було доповнено вивченням есе Х. Ортега-і-Гасета «Убогість і блиск перекладу», уривків 3 твору У. Еко «Сказати те саме» тощо. У межах вивчення філософії пізнання проводився семінар «Переклад, рецепція, розуміння (Переклад як інструмент пізнання та рефлексіі)», підчас якого студенти жваво обговорювали нетрадиційний погляд Н. Автономової на переклад як гносеологічний та рефлексивний ресурс, а не лише один 3 видів професійної діяльності сучасної людини, аналізували наведені автором приклади, доповнювали їх прикладами 3 власного перекладацького досвіду та досвіду читача перекладеної літератури. Результатом проведених занять стало те, що майбутні перекладачі технічної літератури змогли відмовитися від суто практичного розуміння перекладу та перекладацької діяльності, усвідомити місце, яке посідає переклад у філософській картині світу, дізналися про вплив перекладу на розвиток філософії як науки. Отримані знання забезпечили формування у студентів певного рівня професійної свідомості, збудили в них цікавість про дисциплін професійної підготовки, які вивчалися після курсу «Філософія».

До курсу «Основи психології» було введено тему «Психологічні основи діяльності перекладача технічної літератури», у межах якої студенти дізналися про психологічні механізми професійної діяльності перекладача технічної літератури, розглянули поняття «перекладацьке мислення», «перекладацьке пізнання». Підчас вивчення тем «Пам'ять», «Уява», «Увага» викладачі не лише характеризували ці феномени з позиції теорії психології, але й показували, як саме вони реалізуються під час перекладання, як впливають на розвиток перекладача технічної літератури як особистості. На семінарських заняттях студенти навчилися конкретним прийомам розвитку власної пам'яті, методикам концентрування уваги тощо. При цьому 
викладачі професійно спрямованих дисциплін, зокрема дисципліни «Теорія та практика перекладу», мали змогу спостерігати підвищення рівня інтелектуальної лабільності студентів: вони стали більш легко змінювати різні типи діяльності, легше адаптуватися до нового завдання, краще засвоювати матеріал.

Позитивну оцінку від студентів отримав семінар-тренінг «Стресові та екстремальні ситуації в роботі перекладача технічної літератури», під час якого майбутні перекладачі технічної літератури дізналися про стресогенні чинники у їхній майбутній професійній діяльності, розглянули поняття «стресостійкість», «емоційна стійкість» тощо. У практичній частині тренінгу студенти добирали та аналізували стресові та екстремальні ситуації, у яких може опинитися перекладач технічної літератури, розробляли програми діяльності в таких ситуаціях, оволоділи методиками подолання стресу, зокрема прийомами аутогенного тренування.

Ефективним виявилося міждисциплінарне заняття «Перекладацька естафета» на стику дисциплін «Теорія та практика перекладу» та «Основи психології» (схема проведення естафети показана на Рис. 1).

Під час естафети майбутні перекладачі технічної літератури змогли достеменно відчути, як складно мобілізувати набуті професійні знання, уміння та навички в несприятливих умовах, отримали змогу на практиці застосувати відомі їм вправи психологічної регуляції стресових станів. Неочікуваними стали результати проведення естафети: щоразу більш успішними виявлялися не ті учасники команд, які до того демонстрували високі навчальні досягнення, а ті, хто зміг швидко заспокоїтися, «узяти себе в руки», «спокійно розібратися в ситуації», «вгамувати серце» (фрази в лапках узято 3 відповідей студентів, що вони їх надали підчас обговорення, проведеного викладачами теорії та практики перекладу та основ психології з учасниками змагання після заняття).

При цьому зауважимо, що обрана ігрова форма мала не розважальний, а навчальний характер, оскільки успішність проходження учасниками етапів естафети визначалася не швидкістю, а якістю виконаних перекладів, оригінальністю й доцільністю обраних перекладацьких рішень, дотриманнямєдиної перекладацької стратегї̈ команди.

У процесі вивчення теоретичних дисциплін професійного спрямування («Вступ до перекладознавства», «Лінгвістика тексту», «Основи прикладної лінгвістики») зміст лекційних і семінарських занять доповнювався матеріалом про специфіку технічної літератури, особливості їі перекладу, перекладацькі прийоми й допоміжні засоби 3 арсеналу перекладача технічної літератури.

Зрозуміти необхідність фундаментальної теоретичної підготовки перекладачів технічної літератури студенти змогли під час лекції «удвох» 3 теми «Переклад технічної літератури» (у межах курсу «Вступ до перекладознавства»). Матеріал, рекомендований для засвоєння, студенти отримували під час комунікативної взаємодії двох лекторів - «теоретика» (викладач курсу) і «практика» (професійний перекладач технічної літератури). «Теоретик» розглядав переклад технічної літератури $з$ позицій перекладознавчої науки, а «практик» доповнював ці теоретичні відомості прикладами 3 реальної діяльності, розкривав їхнє практичне значення. За результатами лекції майбутні перекладачі технічної літератури не лише глибоко засвоїли традиційно складний для розуміння матеріал, але й продемонстрували високий рівень зацікавленості ним, що мало вияв у значній кількості поставлених ними питань. Цікавим виявилося те, що студенти ставили не лише питання практичного характеру до «практика» (як ми передбачали), але й питання 3 
методології перекладу - до «теоретика», тобто заняття виявило значний мотиваційний потенціал саме до здобуття фундаментальних теоретичних знань 3 теорії перекладу. Опосередковано про це свідчить розповідь працівників університетської бібліотеки про те, що після проведення лекцій «попит» на праці з теорії перекладу, зокрема, книги Л. Бархударова, В. Комісарова, Л. Латишева, З. Львовської, Р. Мін’ярБєлоручева, I. Ревзіна і В. Розенцвейга, Я. Рецкера, А. Федорова; перекладознавчі журнали («Зошити перекладача», «Питання мовознавства», «Світ перекладу») зростав у кілька разів.

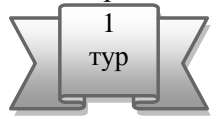

Швидие, швидие

Гравці обох команд по черзі перекладають невеликі тексти технічної літератури (обсягом 150-200 слів). Набір текстів для кожної 3 команд $\epsilon$ однаковим, тексти лежать у тому самому порядку. Правильність перекладу кожного тексту перевіряє журі, оцінюючи його від 1 до 5 балів. перекладати першою, отримує один бал заохочення.

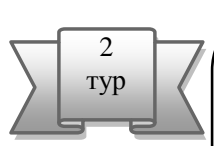

Пошкоджений телефон

Гравець №1 перекладає текст технічної літератури (обсягом 300-350 слів) 3 української мови англійською, потім закриває текст оригіналу таким чином, щоб наступний гравець бачив лише текст перекладу.

Гравець №2 перекладає текст перекладу 3 англійської мови знову українською, потім закриває свій текст оригіналу.

Таким чином гравці обох команд перекладають текст доти, доки останній гравець не перекладе текст українською мовою.

Журі зіставляє отриманий після декількох перекладів текст із оригіналом i оцінює їхню схожість балами від 1 до 10. Швидша команда отримує 1 бал заохочення.

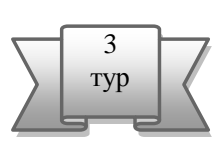

Відповідь залові

Гравці команд по черзі перекладають англійською та пояснюють українські технічні терміни, які їм задають глядачі. Кожна правильна відповідь оцінюється 1 балом. Час продовження туру - по 10 хвилин для кожної команди.

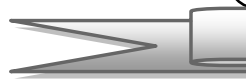

Виграє команда, яка отрималабільшу кількість балів

Рис. 1 Схема проведення перекладацької естафети майбутніх перекладачів технічної літератури

Знання, отримані під час лекції, закріплювалися під час семінарського заняття, на якому майбутні перекладачі технічної літератури мали обговорити та дати відповідь на питання: Що таке технічна література? Які типи технічної літератури можна визначити $з$ точки зору перекладознавчої науки? Чим подібні тексти технічної літератури, створювані українською та англійською мовами? У чому полягає специфіка перекладу технічної літератури? Які прийоми перекладач технічної літератури використовує під час свої професійної діяльності? Які вимоги робота 3 текстами технічної літератури ставить перед перекладачем технічної літератури?

Знання майбутніх перекладачів технічної літератури про технічну літературу як спеціальний текст доповнювалися та розширювалися підчас семінарського заняття на тему «Текст технічної літератури як єдине інформаційне структурне ціле» (дисципліна «Лінгвістика тексту»), на якому розглядалися такі питання, як структура 
тексту технічної літератури з точки зору лінгвістики тексту; специфіка реалізації одиниць семантико-синтаксичного рівня у текстах технічної літератури; темарематичні відношення у текстах технічної літератури та інші. Важливість вивчення цієї теми вбачаємо в тому, що студенти вперше отримали можливість розглянути тексти технічної літератури як мовний феномен поза перекладознавчим аспектом. Як результат, вони змогли побачити, що форма подання повідомлення також є важливим носієм його значення; зрозуміти, як організація створюваних текстів, їхня будова впливають на те, як такі тексти сприймає читач, як вплинути на читача не лише за допомогою лексичних, але й інших мовних і позамовних засобів. Це, у свою чергу, значно вплинуло на якість перекладуваних текстів: ці тексти стали більш точними за своєю формою і стали демонструвати ознаки природного створення (тобто справляти враження не перекладених, а створених носієм мови та без опори на інший текст). Окрім того, засвоєння курсу «Лінгвістика тексту» стало логічним завершенням формування базового когнітивного складника текстоутворювальної компетенції майбутніх перекладачів технічної літератури.

Також було суттєво розширено зміст дисципліни «Основи прикладної лінгвістики» за рахунок модифікації теоретичного наповнення лекцій на тему «Переклад технічної літератури як традиційна галузь прикладної лінгвістики» та «Автоматизований переклад як практична діяльність на перетині перекладознавства та комп'ютерної лінгвістики», а також уведення додаткових семінарів - семінарукруглого столу «Перекладач технічної літератури як упорядник мови. Стилістичний, граматичний, термінологічний аспекти» і семінару за формою «онлайн-дебати» на тему «Опозиція природного та машинного перекладу». Під час цих занять особлива увага приділялася не лише доповненню наявних у студентів знань про лінгвістичне й суспільне значення професійної діяльності перекладача технічної літератури та іï результатів, але й випрацюванню стійкої аргументованої позиції стосовно спірних питань, наявних у цій галузі, зокрема, у проблемі технологічного супроводу перекладу технічної літератури. Додатковий ефект проведених занять убачаємо у формуванні в майбутніх перекладачів технічної літератури таких важливих професійно значущих якостей, як терплячість, толерантність, повага до опонента, уміння приймати та поважати будь-яку позицію безвідносно того, чи особа ії поділяє.

У процесі викладання дисциплін інформаційного циклу здійснювалося формування інформаційно-технологічної компетенції перекладача технічної літератури як основи його/ії професійної успішності на сучасному етапі. Зміст курсів розширився за рахунок доповнення його детальним вивченням саме тих IКТ, які перекладач технічної літератури постійно використовує у професійній діяльності. Зміни, унесені до відповідних навчальних, робочих програм і календарно-тематичних планів, а також вплив засвоєного матеріалу на формування професійних компетенцій перекладача технічної літератури узагальнено в таблиці 1. 
Вплив дисциплін інформаційного циклу на формування професійних знань перекладача технічної літератури

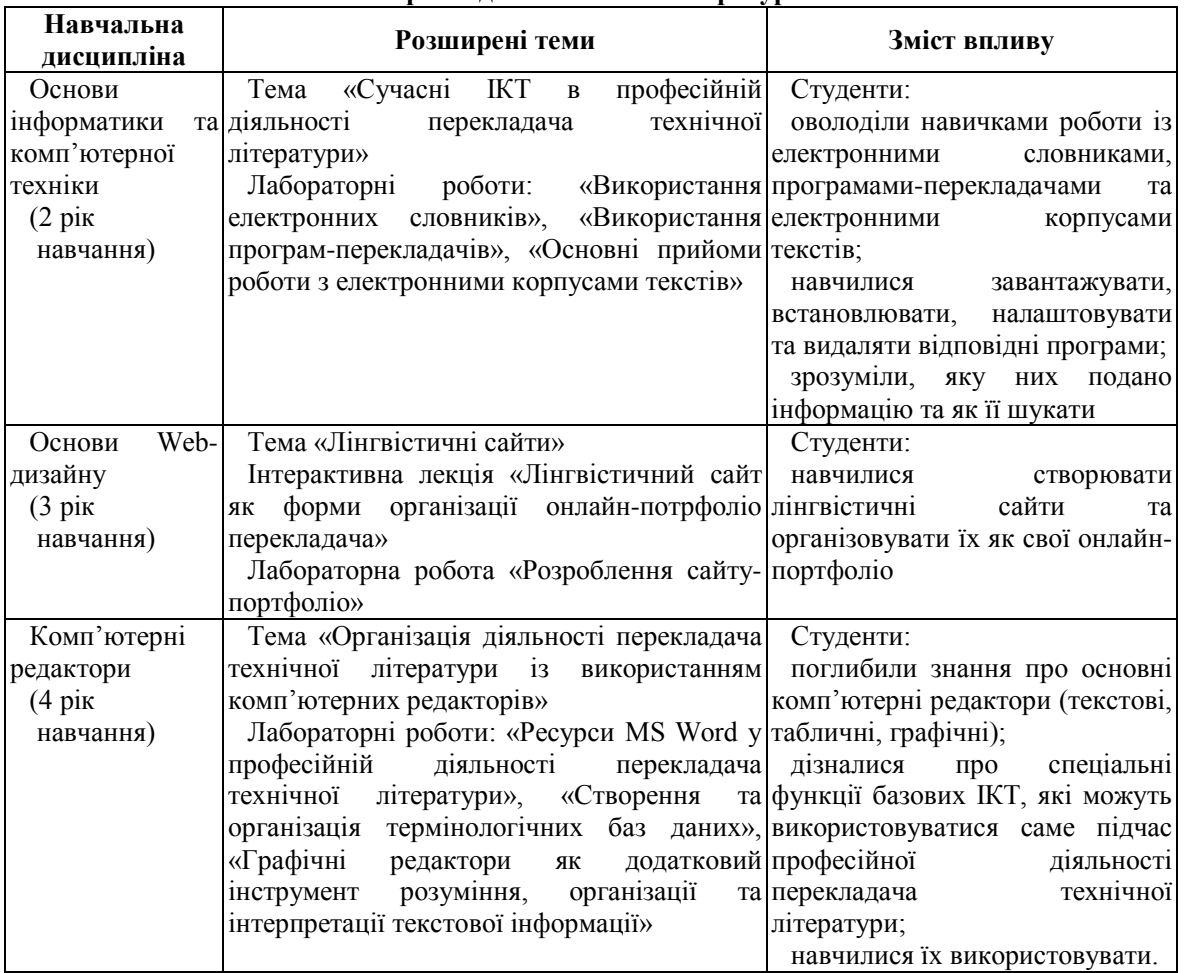

Отже, результати педагогічного експерименту показали, що проблема ефективного формування професійних знань перекладачів технічної літератури може ефективно розв'язуватися у ВТНЗ за умови проведення цілеспрямованої системної роботи викладача і студента. Перспективи подільного дослідження вбачаємо у статистичному обробленні отриманих даних i вдосконаленні та доповненні запропонованих форм, методів і прийомів.

\section{Література}

1. Бахов I. C. Формування професійної міжкультурної компетентності майбутніх перекладачів у вищих навчальних закладах : автореф. дис. на здобуття канд. пед. наук : спец. 13.00.04 «Теорія і методика професійної освіти» / І. С. Бахов. - К., 2011. 20 с. 2. Желясков В. Я. Дидактичне забезпечення процесу навчання майбутніх перекладачів на засадах компетентнісного підходу : автореф. дис. на здобуття канд. пед. наук: спец. 13.00.09 «Теорія навчання»/ В. Я. Желясков. - Кривий Ріг, 2011. 20 с. З. Комиссаров В. Н. Современное переводоведение : [учеб. пособие]/ В. Н. Комиссаров. - М. : ЭТС, 2002. - 424 с. 4. Мацюк О. О. Формування професійної компетентності майбутніх перекладачів засобами інформаційно-комунікаційних технологій : автореф. дис. на здобуття канд. пед. наук: спец. 13.00.04 «Теорія і методика професійної освіти»/ О. О. Мацюк. - Хмельницький, 2011. - 20 с. 
5. Новиков А. И. Реферативный перевод научно-технических текстов / А. И. Новиков, Н. М. Нестерова. - АН СССР, Ин-т языкознания. - М. : Наука, 1991. $146 \mathrm{c}$.

УДК $378.147: 821.111$

Олеся Приймаченко

\section{ПІДХІД ДО ВИВЧЕННЯ АНГЛОМОВНОЇ ЛЕКСИКИ КУРСАНТАМИ НЕПРОФІЛЬНОГО ВНЗ}

Приймаченко О. М. Підхід до вивчення англомовної лексики курсантами непрофільного ВНЗ.

У статті запропоновано підхід до первинної активації незнайомої англомовної лексики 3 використанням PowerPoint-презентацій. Обгрунтовано концептуальні основи підходу та проаналізовано основні методи його реалізації.

Ключові слова:активація англомовної лексики, метод візуалізації, метод складання міні-оповідання, образ, контекст.

Приймаченко О.Н.Подход к изучению англоязычной лексики курсантами непрофильного вуза.

В статье предлагается подход активации незнакомой англоязычной лексики с использованием PowerPoint-презентаций. Описаны концептуальные основы подхода и проанализированы основные методы его реализации.

Ключевые слова:активация англоязычной лексики, метод визуализации, метод составления мини-рассказов, образ, контекст.

Pryimachenko O. M. Approach to English vocabulary learning by cadets of unspecialized High Schools.

The approach of unknown English vocabulary activation with the use of PowerPoint presentation is proposed in the article. Conceptual basics of the approach are substantiated, main methods of its realization are analized.

Key words:English vocabulary activation, method of visualization, method of storytelling, image, context.

Методика навчання іноземної мови в галузі непрофільної лінгвістичної освіти, яка склалась за останні роки у вищих навчальних закладах, накопичила грунтовний досвід методів, прийомів і форм навчання. Результатом цієї роботи, безперечно, можна вважати наявність чималої кількості посібників, підручників, методичних рекомендацій тощо. Усі вони заслуговують на позитивне ставлення та схвалення. Але, на жаль, нині в умовах стрімкого запровадження в організацію освіти інноваційних мультимедійних технологій ці здобутки важко застосувати для розв'язання завдань удосконалення мовної освіти студентів та курсантів. Тому сучасні науковці й освітяни розпочали активний пошук шляхів модернізації процесу викладання іноземних мов у вищій школі, непрофільних навчальних закладах зокрема.

Актуальним завданням у сучасній мовній підготовці 3 іноземної мови $\epsilon$ формування іншомовної комунікативної компетенції студентів (курсантів), при чому акцентується розвиток навичок спонтанного усного мовлення. Відомо, що структурною одиницею мовлення є слово. Будь-яке усне висловлювання залежить від кількості слів, наявних в активному словниковому запасі мовця. У науковій літературі це детермінується як лексична компетенція. Пошук ефективних прийомів первинної 102

Педагогіка вищої та середної школи. - 2014. - Вип. 41 